\title{
EFEK FERMENTASI HIJAUAN POTENSI ANTELMINTIK MENGGUNAKAN Trichoderma sp. TERHADAP JUMLAH EPG FESES DAN ERITROSIT KAMBING
}

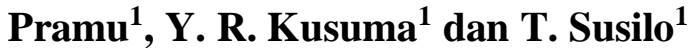 \\ 1) Jurusan Penyuluhan Peternakan, STPP Magelang \\ Jl. Magelang-Kopeng Km 7 Purwosari, Tegalrejo, Magelang \\ E-mail: pramucinagara@yahoo.com
}

Diterima: 23 Agustus 2016

Disetujui: 08 November 2016

\begin{abstract}
ABSTRAK
Pengendalian penyakit cacing nematoda secara efektif dibutuhkan untuk kesehatan ruminansia kecil. Penggunaan antelmintik telah dilaporkan mampu memunculkan potensi resistensi. Oleh karena itu perlu upaya penemuan bahan alami yang lebih ramah lingkungan. Tujuan penelitian adalah untuk mengetahui efek fermentasi pada hijauan daun potensi antelmintik menggunakan Trichoderma sp. terhadap jumlah egg per gram feses cacing $H$. contortus dan jumlah eritosit pada kambing. Trichoderma sp diisolasi dan diperbanyak. Empat macam hijauan potensi antelmintik dikeringkan dengan dijemur untuk kemudia difermentasikan. 15 ekor kambing digunakan dalam uji in vivo dikelopokkan menjadi 5 kelompok; tidak diobati, $5 \times 10^{6}$ Trichoderma $s p$, fermentasi hijauan potensi antelmintik Trichoderma sp, hijauan potensi antelmintik, Levamisol. Terdapat perbedaan nyata $(\mathrm{P}<0,05)$ penurunan jumlah telur cacing terutama antara kelompok yang tidak diobati dengan kelompok perlakuan. Penurunan terbesar terjadi pada pemberian levamisol, kemudian diikuti pada pemberian hijauan potensi antelmintik, kemudian pada pemberian fermentasi hijauan, dan pemberian $5 \times 10^{6}$ Trichoderma $s p$. Terdapat perbedaan yang nyata pada jumlah eritrosit $(\mathrm{P}<0,05)$ antara kelompok perlakuan maupun lama waktu pemberian perlakuan. Pemberian hijauan potensi antelmintik, Trichoderma $s p$, dan fermentasi Trichoderma sp pada kambing yang terinfeksi $H$ contortus masing-masing secara nyata mampu menurunkan jumlah telur cacing $H$ contortus serta meningkatkan jumlah eritrosit.
\end{abstract}

Kata kunci: Trichoderma sp., H contortus, fermentasi, hijauan, antelmintik.

\section{EFFECTS ANTHELMINTIC TRICHODERMA SP. AND FERMENTATION ON THE POTENTIAL ANTHELMINTIC FORAGE LEAVES OF HAEMONCHUS CONTORTUS INFECTION}

\begin{abstract}
Control to Haemonchus contortus effectively needed for small ruminant health. Anthelmintic resistance responded to the effort of finding natural treatment for more environmentally friendly. The purpose of the study was to determine the anthelmintic effect of Trichoderma sp. against the number of eggs per gram feces (EPG) H. contortus and erythrocyte in goats that infected with $H$ contortus and fermentation of forages on the potential anthelmintic. Trichoderma sp were isolated and cultivated using corn media. Four kinds of forage potential anthelmintic dried in the sun for later fermented. 15 goats

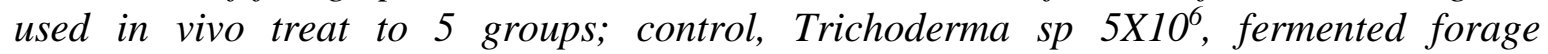
anthelmintic potential of Trichoderma sp, forage potential anthelmintic, Levamisole. There
\end{abstract}


were significant differences decrease $(P<0.05)$ in the number of worm eggs between the untreated group to the treatment group. The largest decrease occurred in the administration of levamisole, followed by the administration of anthelmintic potential forage, forage fermentation, and the administration of $5 \times 10^{6}$ Trichoderma sp. There is significant differences to the number of erythrocytes $(P<0.05)$ between the treatment groups and the time of treatment duration. Administration of anthelmintic potential forage, Trichoderma sp, and Trichoderma sp fermentation in goats with infected to $H$ contortus respectively significant able to reduce the amount of $H$ contortus worm eggs and increase the number of erythrocytes.

Keywords: Trichoderma sp., H contortus, fermentation, forage, anthelmintic.

\section{PENDAHULUAN}

Keberhasilan ternak ruminansia kecil membutuhkan pengendalian nematoda gastrointestinal secara efektif. Program pengendalian berbasis pada penggunaan obat antelmintik sering gagal untuk mengontrol nematoda gastrointestinal karena terjadi peningkatan prevalensi resistensi obat (Waller and Faedo, 1993); (Mortensen et al., 2003). Kasus resistensi juga sudah dilaporkan Haryuningtyas et al., (2001) terjadi di beberapa wilayah di Indonesia.

Beberapa tanaman yang memiliki kandungan tanin telah dilaporkan mampu mengurangi kejadian infestasi cacing. Penelitian penggunaan antelmintik baru menunjukkan bahwa tanaman tanninferous dapat dianggap sebagai potensi alternatif untuk pengendalian infestasi nematoda pada ternak ruminansia kecil (Akkari et al., 2008).

Ahmad et al., (2012) memakai fungi nematofagus dari jenis Duddingtonia flagrans dan Saccharomycer cerevisiae untuk mereduksi larva infektif Haemonchus contortus. Pemanfaatan daun potensi antelmintik dengan teknik fermentasi menggunakan fungi khususnya dari kelompok nematofagus, yang sekaligus memiliki sifat dekomposer, dari jenis Trichoderma belum pernah dipublikasikan.
Tujuan penelitian adalah untuk mengetahui efek fermentasi pada hijauan daun potensi antelmintik menggunakan Trichoderma $s p$. terhadap jumlah egg per gram feses cacing $H$. contortus dan jumlah eritosit pada kambing.

\section{MATERI METODE}

Trichoderma $s p$ diisolasi dan diperbanyak. Empat macam hijauan potensi antelmintik dikeringkan dengan dijemur untuk kemudia difermentasikan. 15 ekor kambing digunakan dalam uji in vivo dikelopokkan menjadi 5 kelompok; tidak diobati, $5 \times 10^{6}$ Trichoderma $s p$, fermentasi hijauan potensi antelmintik Trichoderma $s p$, hijauan potensi antelmintik, Levamisol.

Trichoderma $s p$ diisolasi dan diperbanyak menggunakan media jagung. Eampat jenis hijauan potensi antelmintik dikeringkan dengan cara dijemur untuk kemudian difermentasikan. 15 ekor kambing digunakan dalam uji in vivo dikelopokkan menjadi 5 kelompok yakni; (A) kontrol, (B) 5X106 Trichoderma sp, (C) fermentasi hijauan potensi antelmintik Trichoderma sp, (D) hijauan potensi antelmintik, (E) Levamisol. Setiap kambing diinfeksi dengan $2500 \mathrm{~L}_{3} H$. contortus pada minggu ke-1. Setelah tiga minggu dilakukan pengambilan dan pemeriksaan. Sampel feses dan darah diperiksa setiap dua hari sekali mulai minggu ke-4 hingga 
minggu ke-6 untuk pemeriksaan FEC dan jumlah eritrosit

Percobaan disusun dalam rancangan acak kelompok. Data hasil laboratorium yang terkumpul dideskripsikan dan diuji dengan statistik untuk mengetahui pengaruh perbedaan perlakuan menggunakan analysis of variance (ANOVA) dua arah yang dilanjutkan dengan uji Duncan (Steel dan Torrie, 1995).

Parameter pada pengujian in vivo parameter adalah EPG feses (Whitlock, 1948) dan pemeriksaan darah (jumlah eritrosit).

\section{HASIL DAN PEMBAHASAN}

Hasil penelitian diuraikan sebagai berikut. Terdapat perbedaan penurunan jumlah telur cacing terutama antara kelompok yang tidak diobati dengan kelompok perlakuan. Penurunan terbesar terjadi pada pemberian levamisol, kemudian diikuti pada pemberian hijauan potensi antelmintik, kemudian pada pemberian fermentasi hijauan, dan pemberian $5 \times 10^{6}$ Trichoderma sp.

Penuruan jumlah EPG feses adalah akibat dari penurunan jumlah cacing dewasa dalam abomasum (Gambar 1).

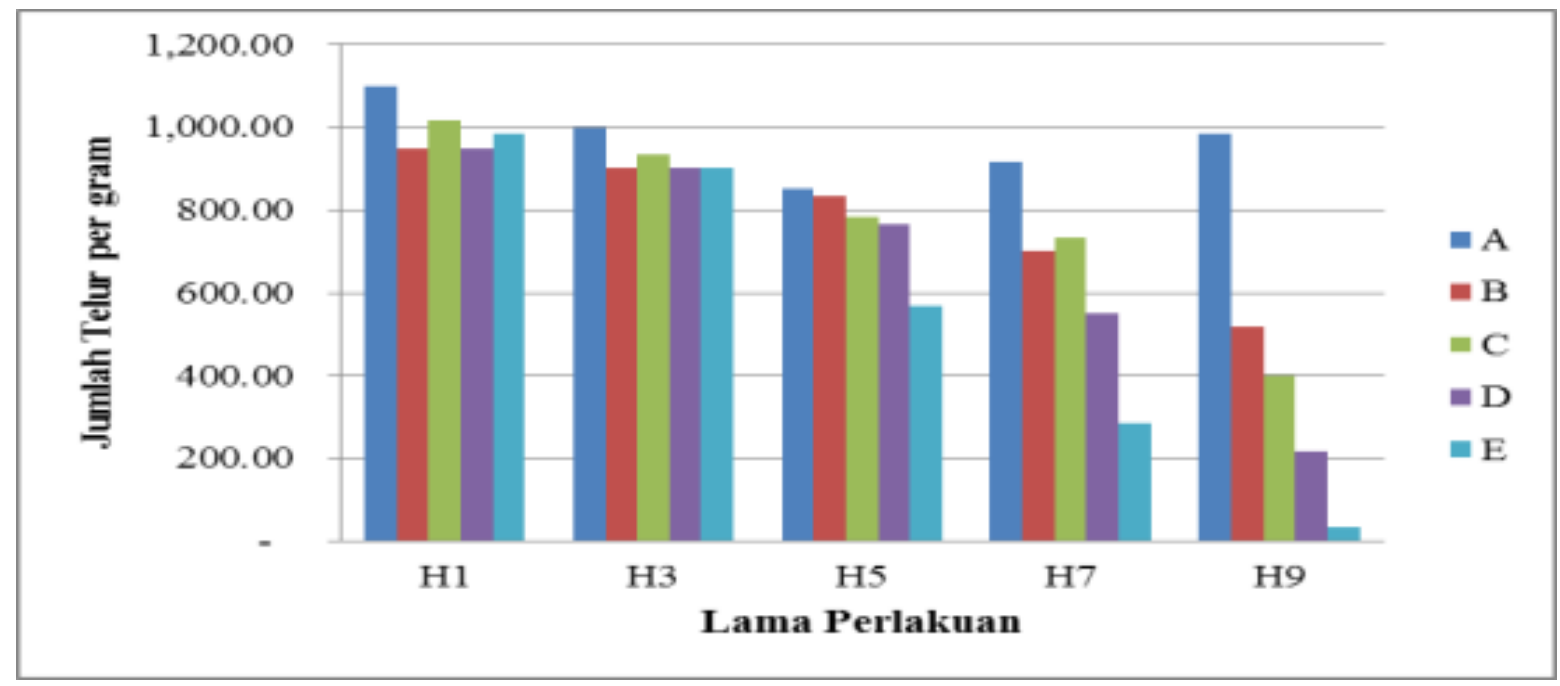

Gambar 1. Jumlah telur per gram tinja masing masing kelompok $(n=3)$ selama sembilan hari. (A) kontrol (tidak diobati), (B) Trichoderma sp, (C) Fermentasi hijauan potensi antelmintik + Trichoderma sp, (D) hijauan potensi antelmintik, (E) Levamisol.

Pengujian data statistik anova dua faktor menggunakan replikasi menjukkan terdapat perbedaan yang nyata $(\mathrm{P}<0,05)$ antara kelompok perlakuan maupun lama waktu pemberian perlakuan. Berdasarkan hasil uji anova tersebut kemudian dilakukan pengujian lebih lanjut menggunakan uji jarak berganda Duncan. Analisis penurunan jumlah telur cacing per gram feses ini untuk mengetahui apakan ada perbedaan yang signifikan baik pengaruh kelompok perlakuan pada setiap lama perlakuan maupun pengaruh lama pemberian perlakuan pada setiap kelompok perlakuan. Tabel 1 menyajikan hasil pengujian jarak berganda Duncan. 
Tabel 1. Rerata jumlah telur cacing (per gram feses) pada setiap perlakuan selama sembilan hari (H1-H9).

\begin{tabular}{cccccc}
\hline \multirow{2}{*}{ Perlakuan } & \multicolumn{5}{c}{ Waktu pengambilan sampel } \\
\cline { 2 - 6 } & H1 & H3 & H5 & H7 & H9 \\
\hline A & $1,100.00^{\mathrm{aW}}$ & $1,000.00^{\mathrm{aW}}$ & $850.00^{\mathrm{aX}}$ & $916.67^{\mathrm{aW}}$ & $983.33^{\mathrm{aW}}$ \\
$\mathrm{B}$ & $950.00^{\mathrm{aW}}$ & $900.00^{\mathrm{aW}}$ & $833.33^{\mathrm{aW}}$ & $700.00^{\mathrm{bX}}$ & $516.67^{\mathrm{bY}}$ \\
C & $1,016.67^{\mathrm{aW}}$ & $933.33^{\mathrm{aW}}$ & $783.33^{\mathrm{bX}}$ & $733.33^{\mathrm{bX}}$ & $400.00^{\mathrm{bY}}$ \\
D & $950.00^{\mathrm{aW}}$ & $900.00^{\mathrm{aW}}$ & $766.67^{\mathrm{bX}}$ & $550.00^{\mathrm{cY}}$ & $216.67^{\mathrm{cZ}}$ \\
E & $983.33^{\mathrm{aW}}$ & $900.00^{\mathrm{aW}}$ & $566.67^{\mathrm{cX}}$ & $283.33^{\mathrm{cY}}$ & $33.33^{\mathrm{dZ}}$ \\
\hline
\end{tabular}

Keterangan: (A) tidak diobati, (B) Trichoderma $s p$, (C) Fermentasi hijauan potensi antelmintik+Trichoderma $s p$, (D) hijauan potensi antelmintik, (E) Levamisol. Nilai rataan yang diikuti oleh superskrip $\left({ }^{\mathrm{a}, \mathrm{b}, \mathrm{c}, \mathrm{d}}\right)$ yang berbeda pada kolom yang sama dan superskrip $\left({ }^{\mathrm{W}}\right.$, $\mathrm{X}, \mathrm{Y}, \mathrm{Z})$ yang berbeda pada baris yang sama menunjukkan perbedaan yang nyata $(\mathrm{P}<0,05)$

Pengaruh kelompok perlakuan pada setiap lama perlakuan diuraikan sebagai berikut. Belum terdapat perbedaan yang nyata pada semua kelompok sampai hari ke-3. Perbedaan yang nyata mulai terjadi pada hari ke-5 yaitu kelompok C (Fermentasi hijauan potensi antelmintik+Trichoderma sp) dan kelompok D (hijauan potensi antelmintik). Sedangkan pada kelompok E (Levamisol) perubahan tampak lebih signifikan. Hari ke-7 tidak terdapat perbedaan yang signifikan antara kelompok B dengan kelompok $\mathrm{C}$ maupun antara kelompok D dengan kelompok E. Hari ke-9 semua kelompok berbeda nyata kecuali kelompok B dan kelompok C.

Pengaruh lama pemberian perlakuan pada setiap kelompok perlakuan diuraikan sebagai berikut. Selama perlakuan kelompok A tidak memiliki perbedaan nyata kecuali pada hari ke-5 mengalami penurunan jumlah telur kemudian naik lagi pada hari ke-9. Kelompok B sampai hari ke-5 tidak mengalami perubahan nyata, baru mulai hari ke-7 dengan hari ke-9 menunjukkan perbedaan nyata. Sedangkan kelompok $\mathrm{C}$, D, dan $\mathrm{E}$ masing-masing sampai hari ke-3 tidak terdapat perbedaan nyata, baru kemudian berbeda nyata pada hari ke-7 dengan ke-9 pada masing masing kelompok.
Waktu terjadi penurunan yang signifikan berkorelasi dengan mekanisme nematosida masing-masing kelompok perlakuan di dalam abomasum kambing. Penurunan terbesar pada kelompok E (levamisol) tidak menjadikan perlakuan ini direkomendasikan karena selain mahal juga saat ini multipel resistensi terhadap antelmentika golongan benzimidazole, levamizole dan macrolitic lactones telah terjadi hampir di seluruh dunia dan prevalensinya terus meningkat dari tahun ke tahun (Waller et al., 1994). Resistensi antelmintik direspon dengan melakukan upaya penemuan bahan alami (non sintetis) dengan toksisitas rendah untuk mengurangi beban cacing pada ternak (Alawa et al., 2003).

Pengujian data sampel jumlah eritrosit menggunakan statistik anova dua faktor dengan replikasi menunjukkan terdapat perbedaan yang nyata $(\mathrm{P}<0,05)$ antara kelompok perlakuan maupun lama waktu pemberian perlakuan (Tabel 2). 
Tabel 2. Rerata jumlah eritrosit (juta/ $\mu$ l) pada setiap perlakuan selama sembilan hari (H1-H9).

\begin{tabular}{cccccc}
\hline \multirow{2}{*}{ Perlakuan } & \multicolumn{5}{c}{ Waktu pengambilan sampel } \\
\cline { 2 - 6 } & $\mathrm{H} 1$ & $\mathrm{H} 3$ & $\mathrm{H} 5$ & $\mathrm{H} 7$ & $\mathrm{H} 9$ \\
\hline $\mathrm{A}$ & $12.62^{\mathrm{b}}$ & $12.61^{\mathrm{b}}$ & $12.78^{\mathrm{b}}$ & $11.12^{\mathrm{b}}$ & $11.61^{\mathrm{b}}$ \\
$\mathrm{B}$ & $12.88^{\mathrm{b}}$ & $13.31^{\mathrm{b}}$ & $13.14^{\mathrm{b}}$ & $13.00^{\mathrm{b}}$ & $11.21^{\mathrm{b}}$ \\
$\mathrm{C}$ & $13.11^{\mathrm{b}}$ & $12.55^{\mathrm{b}}$ & $12.86^{\mathrm{b}}$ & $11.98^{\mathrm{b}}$ & $12.95^{\mathrm{b}}$ \\
$\mathrm{D}$ & $10.75^{\mathrm{a}}$ & $13.16^{\mathrm{b}}$ & $13.00^{\mathrm{b}}$ & $11.40^{\mathrm{b}}$ & $12.02^{\mathrm{b}}$ \\
$\mathrm{E}$ & $12.42^{\mathrm{b}}$ & $14.85^{\mathrm{b}}$ & $15.25^{\mathrm{c}}$ & $12.18^{\mathrm{b}}$ & $13.63^{\mathrm{b}}$ \\
\hline
\end{tabular}

Keterangan: (A) tidak diobati, (B) Trichoderma $s p$, (C) Fermentasi hijauan potensi antelmintik+Trichoderma $s p$, (D) hijauan potensi antelmintik, (E) Levamisol. Nilai rataan yang diikuti oleh superskrip $\left({ }^{\mathrm{a}, \mathrm{b}, \mathrm{c}, \mathrm{d}}\right)$ yang berbeda pada kolom yang sama menunjukkan perbedaan yang nyata $(\mathrm{P}<0,05)$

Pengujian lebih lanjut menggunakan uji jarak berganda Duncan menunjukkan kecenderungan tidak ada perbedaan nyata $(\mathrm{P}>0,05)$ baik pengaruh kelompok perlakuan pada setiap lama perlakuan maupun pengaruh lama pemberian perlakuan pada setiap kelompok perlakuan. Perbedaan hanya terdapat pada pengaruh kelompok perlakuan pada lama perlakuan khususnya hari ke-1 dan hari ke-5. Hari ke1 terdapat perbedaan yang nyata pada kelompok D (hijauan potensi antelmintik) dengan kelompok lain. Hari ke-5 terdapat perbedaan yang nyata pada kelompok $\mathrm{E}$ (Levamisol).

Perbedaan pada masing-masing perlakuan menunjukkan bahwa ternak melakukan adaptasi terhadap kejadian infestasi $H$. contortus. Schalm et al. (1975) berpendapat berkurannya jumlah eritrosit yang beredar direspon dengan sistem eritropoietik dalam memproduksi darah. Dalam kondisi awal kehilangan darah diimbangi dengan peningkatan kinerja eritripoiesis sehingga terjadi keseimbangan antara kehilangan darah dan produksi darah. Peningkatan produksi darah dapat terlihat dari munculnya gejala anisositosis.

Peningkatan produksi eritrosit akan menyebabkan peningkatan zat besi di dalam plasma bersamaan dengan laju kehilangan zat besi di dalam feses. Akibatnya cadangan zat besi di dalam tubuh kambing yang terserang $H$. contortus akan terus menurun. Selanjutnya akan terjadi kelelahan sistem eritropoiesis karena kekurangan besi dan protein. Jumlah sel darah merah dalam tubuh selalu diproduksi berdasarkan kebutuhan sel-sel tubuh akan oksigen. Setiap keadaan yang menyebabkan penurunan transportasi jumlah oksigen ke jaringan biasanya akan meningkatkan kecepatan produksi sel darah merah (Guyton dan Hall, 1997).

\section{SIMPULAN DAN SARAN}

\section{Simpulan}

Pemberian hijauan potensi antelmintik, Trichoderma $s p$ dan fermentasi Trichoderma sp pada kambing yang terinfeksi $H$. contortus masing-masing secara nyata mampu menurunkan jumlah telur cacing $H$. contortus serta meningkatkan jumlah eritrosit.

\section{Saran}

Perlu penelitian in vivo lebih dalam untuk mengetahui interaksi fungi nematofagus Trichoderma sp. dan daun potensi anthelmintik dalam mengurangi beban infeksi $H$. contortus khususnya di 
dalam abomasum serta kemungkinan efek negatifnya terhadap ternak

\section{DAFTAR PUSTAKA}

Ahmad, RZ., dan Y Sani. 2007. Pengaruh Pemberian Duddingtonia flagrans Dan Saccarimyces cerevisiae Terhadap Morfologi Alat Reproduksi Cacing Haemonchus contortus Pada Domba. Prosiding. Seminar Nasional Teknologi Peternakan dan Veteriner 2007.

Ahmad, RZ., F Satrija, N Sukarno, dan FH Pasaribu. 2012. Pemakaian Duddingtonia flagrans dan Saccharomycer cerevisiae dalam Mereduksi Larva Infektif Haemonchus contortus. Jurnal Veteriner Vol.13 No.I: 70-76.

Akkari, H., M.A. Darghouth, and H.B. Salem. 2008. Preliminary Investigations of The antinematode Activity of Acacia cyanophylla Lindl.: Excretion Gastrointestinal Nematode Eggs in Lambs Browsing A. cyanophylla With and Without PEG or Grazing Native Grass. J. Small Rum Res. 74: 78-83.

Alawa, C.B.I., A.M. Adamu, J. O. Gefu, , O.J. Ajanusi, P.A. Abdu, N.P. Chiezey, J. N. Alawa and D.D. Bowman. 2003. In vitro screening of two Nigerian medicinal plants (Vernonia amygdalina and Annona senegalensis) for anthelmintic activity. J. Vet. Parasitol. 113: 7381.

Beauchemin, K. A., D. Colombatto, D. P. Morgavi. And W. Z. Yang. 2003. Use of exogenous fibrolytic enzymes to improve feed utilization byruminant. J. Anim. Sci.

(E.Suppl. 2) : E 37-E 47

Douch GBC, Morum PE, Rabel B.1996. Secretions of Antiparatites Substances and Leucotrienes From Ovine Gastrointestinal Tissue and Issolated Mocosa Mast Cells. Int J Parasitol 26:205-211.

Harman. G. E., C. R. Howel., A. Viterbo., I. Chet., and M. Lorito. 2004. Trichoderma spesies Opportunistic, Avirulent Plant Symbionts. Nature Review Microbiology Volume 2.www.nature.com. Diakses tanggal 20 Januari 2014.

Haryuningtyas D, Beraijaya dan G.D. Gray. 2001. Resistensi antelmintik golongan benzimidazole pada domba dan kambing di Indonesia. Pros. Seminar Nasional Teknologi Peternakan dan Veteriner. Bogor, 17 - 18 September 2001. Puslitbang Peternakan, Bogor.Makkar, H.P.S. 1999. Role of tannins and saponin in nutrition. In Proceeding of The Seventh Scientific Workshop in Tromso : Effects of Antinutritional Value of Legume Diets.

Molan, A. L., G. C. Waghorn, B. R. Min, and W. C. McNabb. 2000. The effect of condensed tanin from seven herbages on Trichostrongylus colubriformis larval migration in vitro. Folia Parasitol. 47:39-44.

Mortensen, L.L., Williamson, L.H., Terrill, T.H., Kircher, R., Larsen, M., Kaplan, R.M. 2003. Evaluation of prevalence and clinical implications of anthelmintic resistance in gastrointestinal nematodes of goats. Journal of the American Veterinary Medical Association 23, 495-500. 
Ojeda-Robertos, NF., Torres-Acosta, JF., Ayala-Burgos AJ., Sandoval-Castro CA., Valero-Coss R., and Mendozade-Gives P. 2009. Digestibility of Duddingtonia flagrans chlamydospores in ruminants: in vitro and in vivo studies. BMC Veterinary Research 2009, 5:46 doi:10.1186/1746-6148-5-46.

Diakses dari http://www.biomedcentral.com/ 1746-6148/5/46 tanggal 12 November 2012.

Steel RGD dan JH Torrie. 1995. Principles and Procedures of Statistic. Edisi Bahasa Indonesia. Gramedia Pustaka Utama, Jakarta.

Supriyati, T. Haryati, I-G.M. Budiarsana dan I-K. Sutama. 2010. Fermentasi Jerami Padi Menggunakan Trichoderma viride. Prosiding. Seminar Nasional Teknologi Peternakan dan Veteriner 2010. Bogor.

Waller P.J., and Faedo M., 1993. The prospects for the biological control of the free-living stages of nematode parasites of livestock, Int. J. Parasitol. 26 915-925.

Waller, P.J, M. Larsen, M. Faedo, and D.R. Hennesy. 1994. The potential of nematophagous fungi to control the free-living stages of nematode parasites of sheep: in vitro and in vivo studies. Veterinary Parasitology 51: 289-299.

Whitlock, H.R., 1948. Some modifications of the McMaster helminth eggcounting technique apparatus. $J$. Counc. Sci. Res. 21, 177-180.
Widjajanti, S., E. Estuningsih, S. Partoutomo, H.W. Radsma, T.W. Spithill, dan D. Piedrafita. 2002. Hubungan Antara Jumlah Infestasi Cacing Hati Dengan Nilai Total Eosinofil Dan Nilai PCV Pada domba yang Diinfeksi Fasciola gigantica. Prosiding. Seminar Nasional Telnologi Peternakan dan Veteriner. Puslitbang Peternakan, Balitbang Pertanian, Deptan, Bogor, 363-369. 